\title{
Fragmentation of Broken Men and Human Rights in a Globalized World
}

\author{
Dr. Mizanur Rahman* \\ You write 'Injustice' on earth \\ We will write 'Revolution' in the sky. \\ -Amir Aziz
}

\section{Introduction}

The second half of the twentieth century witnessed a remarkable recognition of human rights as universal rights. Despite the dichotomy and in my opinion, deliberate misconstruction of the notion of human rights into positive and negative rights, there was a visible consensus among jurists and statesmen about the preeminent significance of human rights for emancipation of human beings and building an egalitarian society. Human rights in theory and practice, had assumed such a pinnacle position in international relations and domestic policy making that political scientists were tempted to dub the era as "The End of History" and the people inhabiting the globe in the $20^{\text {th }}$ century as "the Last Man".

The contention is acceptable only as much as it recognized the principle of 'equality of all persons' irrespective of caste, class, sex, faith, nationality. Regrettably, however, history is full of evidence that the 'equality' was applicable only in relation to and among the 'equals' and the inherent discriminations in social and political life of the individuals were never eroded by the strict implementation of the high sounding principle of 'equality'. Those who were not 'equals', i.e. the 'Broken men'2always resided outside the ambit of human rights protective vest. Quite interestingly, human rights jurisprudence was given such a flavor to create an illusory equality of all to conclude that the case of the Broken Men was an unfortunate incident of the past and has no relevance in an era of universal human rights culture.

This article is an attempt to break this myth and further show that not only that the Broken men had been a constant reality even during the hey days of human rights but that the twenty-first century is witnessing the unfortunate reincarnation and fragmentation of the Broken Men in such inhuman ways that the very foundations of human civilization have come under serious threat in today's globalized world. In order to do this, we need to analyze, albeit very briefly, the nature and content of

\footnotetext{
* Professor, Department of Law and Director, Centre for Advanced Legal Studies (CALS), University of Dhaka.

Francis Fukuyama, The End of History and the Last Man (Free Press 1992) 418.

2 For a definition of Broken Men, see sub-heading "Human Dignity and Broken Men" in the article.
} 
human rights, identify the Broken Men and shed light on some of the manifestations of threats to the Broken men that make the whole idea of 'equality' and 'human rights' a nullity.

\section{Human Rights}

Human rights are literally the rights that one has simply because of the fact that he is born as a human being, is a human being. Human rights are equal rights: one either is or is not a human being, and therefore has the same human rights as everyone else (or none at all). Human rights also are inalienable rights: one cannot stop being human, no matter how badly one behaves or how barbarously one is treated. And they are universal rights, in the sense that today we consider all members of the species Homo Sapiens "human beings" and thus holders of human rights. Similarly, human rights are indivisible in the sense that they cannot be segregated into a hierarchical order where civil and political rights are considered as primary, 'true' rights and economic, social and cultural rights are relegated to a subordinated, secondary position and subject to not immediate but progressive realization owing primarily to their 'resource-dependent' nature'. Indivisibility of human rights thus also refer to the intricate relationship of 'interdependence' of different types of human rights.

There have been some debates about the cultural contexts in which human rights are to be ensured bringing in the notion of cultural relativism. Today it is more than evident that 'right to culture' itself is a human right, and to that extent the rigidity and legitimacy of 'cultural relativism' is diluted. ${ }^{4}$

There has also been an uproar, emanating primarily from the newly independent (developing) countries gaining self-rule during the period of decolonization (from 1960 to 1980 particularly), that the highly acclaimed Universal Declaration of Human Rights, 1948 (UDHR) may be called 'universal' only with wide stretching of imagination. They contend that the overwhelming majority of the member-states of the United Nations did not and because of their non-existence could not participate in the process of the drafting of the UDHR, and this document is embodiment of ethical and moral standards of Western civilization. The ethos, aspirations and principle mores of life of the oriental peoples were never accommodated in the UDHR. Therefore, human rights jurists as well as statesmen of this hemisphere do not tire in repeating the complaint that the UDHR is basically a "Euro-centric' document

3 See more on nature of human rights, Mizanur Rahman, 'Why Human Rights?' in Prof. Dr. Mizanur Rahman (ed), Human Rights: Theory, Law and Practice in Bangladesh (New Warsi Book Corporation 2018) 7-16; See also, Jack Donnelly, Universal Human Rights in Theory and Practice ( $3^{\text {rd }}$ edn, Cornell University Press 2013) 7-23.

4 Mizanur Rahman, 'Keynote paper: Stand Up for Your Rights' (University of Asia Pacific Human Rights Day Conference, Dhaka, December 2019) 3-4. 
imposed on the whole of the international community through the mechanism of the membership of the United Nations. ${ }^{5}$

Despite non-participation of the newly- independent countries in the framing of the UDHR or subsequently, the two basic covenants of the international bill of rights, I would humbly submit that these documents enshrine and focus on the fundamental essence of human rights- 'human dignity to be precise, and this 'dignity' as a value is obviously universal though the content of 'dignity' might have a cultural component/shade and understood differently in different times, places and societies. ${ }^{6}$

\section{3. 'Human Dignity'- the essence of human rights}

It has been argued that notions of human dignity have underlain the political practices of most societies. It is now historically proven that in the pre-modern world, dignity was not seen as an inherent feature of all humans but as an attribute of the few. Rather than a universal principle of equality, dignity functioned as a particularistic principle of hierarchy. ${ }^{7}$ Professor Donnelly traces three interrelated features of the Roman conception of dignity. ${ }^{8}$ First, "dignity" was a term of hierarchical distinction, an attribute of a distinguished few (patricians as opposed to the plebeians and others) that marked them off from the vulgar masses. "Dignitas was the status that dignitaries had- a quality that demanded reverence from the ordinary common person."9

Second, "dignity" was a virtue - or the consequence or reward of virtue - in the Aristotelian sense of a learned habit or disposition that realizes human excellence. Some or even all people may have a potential for virtue, which is the proper natural end of humans. "Dignity, in Latin usage, refers especially to that aspect of virtue or excellence that makes one worthy of honour - which, as Aristotle put it, accompanies virtue as its crown." 10

Third, "dignity" was specially connected with public appearance. "In Rome the original meaning of dignitas referred to an acquired social and political status, generally implying important personal achievements in the public sphere and moral integrity". ${ }^{11}$ Although dignitas certainly had an inner basis, it referred particularly to

5 ibid 4.

6 ibid 5.

7 Donnelly (n3) 121.

8 ibid 122.

9 Andrew Brennan and Y.S. Lo, 'Two Conceptions of Human Dignity: Honor and Self-Determination' in Jeff Malpes and Norelle Lickiss (eds), Perspectives on Human Dignity: A Conversation (Springer 2007) 44.

${ }^{10}$ Susan M. Shell, 'Kant on Human Dignity' in Robert P. Kraynak and Glenn Tinder (eds), In Defense of Human Dignity: Essays for Our Times (The University of Notre Dame Press 2003) 53.

${ }^{11}$ Izhak Englard, 'Human Dignity: From Antiquity to Modern Israel's Constitutional Framework' (1999-2000) 21 Cardozo Law Review 1903, 1904. 
"the outer aspect of a person's social role which evokes respect, and embodies the charisma and the esteem residing in office, rank or personality". ${ }^{12}$

Dignitas, in sum, was a virtue of great people, those meriting special honour or distinction. Practices of dignity involved public recognition and respect - granted by one's peers, the vulgar, society and the polity - that marked off the dignified as excellent, in the sense of excelling. Dignitas was "a manifestation of personal authority, majesty, greatness, magnanimity, gravity, decorum and moral qualities". ${ }^{13}$ The "worth" to which dignity referred was a feature of the few rather than the manylet alone all. ${ }^{14}$

Thus, the above mentioned authorities 'hijacked' dignity of the common man and put it as a jewel in the crown of the few blessed ones. All but the blessed ones became the 'Broken Men'.

\section{Universality of Human Dignity}

How valid is the claim that 'dignity' is an attribute of a few and not common to all persons? Let us see how Cicero approaches this question:

It is essential to every inquiry about duty that we keep before our eyes how far superior man is by nature to cattle and other beasts: they have no thought except for sensual pleasure and this they are impelled by every instinct to seek; but man's mind is nurtured by study and meditation...

From this we see that sensual pleasure is quite unworthy of the dignity of man [dignam hominis]... if we will only bear in mind the superiority and dignity of our nature [natura excellentia et dignitas], we shall realize how wrong it is to abandon ourselves to excess and to live in luxury and voluptuousness, and how right it is to live in thrift, self-denial, simplicity, and sobriety. ${ }^{15}$

Thus, Cicero does attribute dignity to humans in general. This is probably the earliest preserved usage in the classical corpus that can be comfortably translated as "human dignity." In tune with this spirit, Peter Berger claims that "dignity, as against honour, always relates to the intrinsic humanity divested of all socially imposed roles or norms. It pertains to the self as such, to the individual regardless of his position in society." 16

${ }^{12}$ Hubert Cancik, "Dignity of Man" and "Persons"" in David Kretzmer and Eckart Klein (eds), The Concept of Human Dignity in Human Rights Discourse (Brill 2002) 19.

${ }^{13}$ See, Englard (n 11).

${ }^{14}$ Donnelly (n 3) 122.

${ }^{15}$ M. Tullius Cicero, 'De officiis' (Walter Miller (tr), Harvard University Press 1913).

${ }^{16}$ Peter Burger, 'On the Obsolescence of the Concept of Honour' in Stanley Hauerwas and Alasdair MacIntyre (eds), Revisions: Changing Perspectives in Moral Philosophy (The University of Notre Dame Press 1983) 176. 
That human dignity is a common attribute of all human beings is a theme underlying all major religious doctrines. Genesis underlines an understanding of dignity that dominated the Western/Christian world for over a millennium and continues to be a powerful presence in contemporary discussions.

So God created man in his own image, in the image of God created

He him; male and female created he them.

And God blessed them, and God said unto them, Be fruitful,

and multiply, and replenish the earth, and subdue it: and have

dominion over the fish of the sea, and over the fowl of the air, and

over every living thing that moveth upon the earth. (Gen. 1.27-28)

Undoubtedly, this placement — below God but above the rest of His creation gives humans a certain dignity distinguishing them from the rest of the living world.

It is often argued and probably not without strong foundations that the particularistic elements of Hinduism's hierarchical conception of reality, which not only on its face but especially in the practice of the caste system seems deeply incompatible with human rights. ${ }^{17}$ The Hindu tradition, however, also includes universalistic dimensions that ring it into a closer relationship with contemporary human rights ideas.

A certain universalism can be found even in the ancient texts. For example, the Laws of Manu, the most revered — and most conservative and "Brahminic" — of the ancient legal texts, identifies five virtues that apply to all four varnas: abstention from injuring others, truthfulness, abstention from anger or theft, purity, and control over the organs.

The bhakti or devotional tradition offers a very different kind of universalism namely, the promise of salvation through devotion alone. For example, in the Bhagavad Gita, Krishna offers liberation through devotional discipline to members of low and high caste alike and even to women, who are largely excluded from traditional Brahminic religious practice. By downplaying caste differences at the most fundamental spiritual level, this lays a certain foundation for movement toward a social egalitarianism more compatible with modern ideas of human rights.

At the broadest cosmological level, the oneness of all reality is also a powerful support for universalism. Donnelly presents ${ }^{18}$ (18) the following account of the varnas from the Brhadaranyaka Upanishad (1.4.11-15):

11. In the beginning this [universe] was Brahman - One only. Being one only, he had not the power to develop. By a supreme effort he brought forth a form of the Good, princely power [ksatra]...

\footnotetext{
${ }^{17}$ See more, Donnelly (n 3) 145-158.

18 ibid 154.
} 
12. He had no power to develop further. He brought forth the common people [vis]...

13. He had no power to develop further. He brought forth the class of serfs [Sudra]...

14. He had no power to develop further. By a supreme effort he brought forth a form of the Good - Dharma... Right and law [dharma] are the same as truth...

15. This Brahman [One divine being], then, is [at the same time] the princely power and class, the Common people, and the serfs.

The sense of a single order under one all-encompassing dharma is striking.

Islam presents a more comprehensive picture of the oneness of all human beings and corresponding dignity of the human soul as a representative of the Creator. The Quran proclaims, "And indeed We have honoured the Children of Adam, and We have carried them on land and sea, and have provided them with At-Tayyibat (lawful good things), and have preferred them to many of those whom We have created with a marked preferment." [Sura 17:70]

The common good is for the common people. Says the Quran: "Allah, it is He Who has subjected to you the sea, that ships may sail through it by His Command, and that you may seek of His Bounty, and that you may be thankful.

And has subjected to you all that is in the heavens and all that is in the earth; it is all as a favour and kindness from Him. Verily, in it are signs for a people who think deeply." [Sura 45:12.13]

Almost in a repetitive tone, and to further emphasize the oneness of the human creation, the Quran elsewhere states: "And He has subjected to you the night and the day, and the sun and the moon; and the stars are subjected by His Command. Surely, in this are proofs for a people who understand.

And whatsoever He has created for you on the earth of varying colours [and qualities from vegetation and fruits (botanical life) and from animals (zoological life)]. Verily, in this is a sign for a people who remember.

And He it is Who has subjected the sea (to you), that you eat thereof fresh tender meat (i.e. fish), and that you bring forth out of it ornaments to wear. And you see the ships ploughing through it, that you may seek (thus) of His Bounty (by transporting the goods from place to place) and that you may be grateful." [Sura16:12-14]

As if manifesting the principle of non-discrimination with regard to enjoyment of all the fruits of creation by all and sundry, the Quran proclaims' " $\mathrm{He}$ it is Who created for you all that is on earth..." [Sura2:29]

If religions are for human beings and if religious practices have over time transformed into social practices, traditions and defined ways of life, the above mentioned discussion is sufficient testimony to the fact that human dignity as an 
inherent human quality is universal. Universality of human dignity can also be defined as a core characteristic of human rights. That was in fact the case till the arrival/emergence of the Broken Men.

\section{Human Dignity and Broken Men}

Since dignity is an inherent attribute, all living creatures born as humans are entitled to it on an equal measure. Such was the matter of things till the time the primitive class-less society based on the principle of 'equality of all' broke apart giving birth to antagonistic classes. Writes Engels:

Since the exploitation of one class by another is the basis of civilization, its whole development moves in a continuous contradiction. Every advance in production is at the same time a retrogression in the condition of the oppressed class, that is, of the great majority. What is a boon for the one is necessarily a bane for the other; each new emancipation of one class always means a new oppression of another class. The most striking proof of this is furnished by the introduction of machinery, the effects of which are well known today. And while among barbarians... hardly any distinction could be made between rights and duties, civilization makes the difference and antithesis between these two plain even to the dullest mind by assigning to one class pretty nearly all the rights, and to the other class pretty nearly all the duties. ${ }^{19}$

In other words, the majority people became broken- thrown out of the hitherto existing equilibrium in the society and composed a new class, the exploited. Their dignity was shattered, trampled and initially they were reduced to the status of chattels with a human soul! This is the picture we have of the slaves from the annals of history. Thus, the history of 'civilization' began with a crushing blow to the principle of universality of human dignity by denying the same to the vast majority of the people. So the advent of civilization corresponds to the emergence of 'Broken Men'. Elsewhere, Engels noted with absolute clarity that "with the dissolution of these primeval communities society begins to be differentiated into separate and finally antagonistic classes." 20

A reputed philosopher of the XXth century, Rene Mercic stressed the importance of human dignity as the point of convergence of certain contextual elements which sustain the structure of every order of positive law. ${ }^{21}$ The three thousand or so cultures that have been observed reveal certain points of remarkable uniformity regarding the common nature of man and human dignity, as well as the dignity of

${ }^{19}$ Friedrich Engels, 'Origin of Family, Private Property and State' in Karl Marx and Friedrich Engels (eds), Selected Works (Progress Publishers 1975) 582.

20 See, Friedrich Engels, 'Engels' Note to the English Edition of 1888 of the Manifesto of the Communist Party' in Karl Marx and Friedrich Engels (eds), Selected Works (Vol 1, Progress Publishers 1977) 109.

${ }^{21}$ Christopher Gregory Weeramantry, Equality and Freedom: Some Third World Perspectives (Sarvodaya Publishers 1999) 132. 
every individual human being as an important aspect of this common nature. Based on this finding Justice Weeramantry concludes that "dignity is a concomitant of equality and there can be no equality where this dignity is violated ... what really dehumanizes man is not poverty or lack of food or clothes or money, but lack of dignity.",22

Conception of dignity is based on the foundational principle that "all human beings, irrespective of their perceived differences, are equal and deserve equal protection of the laws", and hence, "the system of laws instituting differences among individual's social positions and creating stratified identities establish immoral basis for the differential treatment of people by the State based on social origin and other perceived variations, as so that is not valid and acceptable". ${ }^{23}$ Professor Sangroula argues that as a holder of 'dignity' every individual is entitled to five basic rights- in his words the First rights, which he further names as the Right to have Rights. ${ }^{24}$ These five rights are: (a) the right to inviolability of physical integrity of person under every circumstance; (b) the right to inviolability of personal autonomy of individual or personhood (worth of person); (c) the right to freedom of choice of profession, ideology, faith and way of life; (d) the right to education as the most important service from the State providing better employment and life opportunities; and (e) the right to income generation activities - participate in the economic enterprise. He further contends that "the violation or impairment of any of these rights (read elements of dignity-M.R.) will push the person in the state of deprivation". 25

Unfortunately, this is what happens with the dissolution of the class-less society and its transformation into a society with classes, more importantly antagonistic classes. Those at the bottom, far from the epicenter of power, ripped off their property (under common ownership in pre-class society), found themselves as no longer the subjects but the objects of law - a mechanism hitherto non-existing but now considered indispensable to subjugate the powerless - the Broken men. Engels' observations are immensely penetrating and eye-opening:

But this is not as it ought to be. What is good for the ruling class should be good for the whole of the society with which the ruling class identifies itself. Therefore, the more civilization advances, the more it is compelled to cover the ills it necessarily creates with the cloak of love, to embellish them, or to deny their existence; in short, to introduce conventional hypocrisy - unknown both in previous forms of society and even in the earliest stages of civilization - that culminates in the declaration: The exploiting class exploits the oppressed class solely and exclusively in the interest of the exploited class itself; and if the latter fails to appreciate this, and even

\footnotetext{
22 ibid 132.

${ }^{23}$ Dr. Yubaraj Sangroula, Right to have Rights (Lex \& Juris Publications 2018) 32.

24 ibid.

${ }^{25}$ ibid 26.
} 
becomes rebellious, it thereby shows the basest ingratitude to its benefactors, the exploiters. $^{26}$

Thus, for us, the oppressed class is composed of the Broken Men. While the proponent of the Broken Men theory, B.R. Ambedkar ${ }^{27}$ confined the term to 'survivors of tribal warfare ... who floated around looking for subsistence in constant danger', we venture to expand the horizons of the Broken Men to include all oppressed classes, the marginalized peoples, the downtrodden and the have-nots who have been ripped off their dignity in one form or the other.

In Ambedkar's understanding Broken Men were part of different nomadic tribes that were defeated in battle. That is all. In this minimal description, we are also provided an essential lesson of what we are as subjects. In the primordial scene of battle, we are equal subjects. In this sense this originary battle is an egalitarian one, in the sense that in it humans fought as equals and not as a part of society based on hierarchical structure. The Broken Men all came from different tribes in different places, who in the contingencies of history, found themselves on the losing side. That is all we are: victims of a contingent unfolding of history, with no particular reason for being in the current state of subjugation we are held in. In this egalitarian battle which produces Broken Men, there is no hierarchy of merit, nor divine cycle of karma and gunas, only two warring factions fighting for survival. ${ }^{28}$

Marx and Engels explained these battles somewhat differently — "The history of all existing society is the history of class struggles." ${ }^{29}$ Writing more than 170 years ago, they mentioned,

In the earlier epochs of history, we find almost everywhere a complicated arrangement of society into various orders, a manifold gradation of social rank. In ancient Rome we have patricians, knights, plebeians, slaves; in the Middle Ages, feudal lords, vassals, guild-masters, journeymen, apprentices, serfs; in almost all of these classes, again, subordinate gradations.

The modern bourgeois society that has sprouted from the ruins of feudal society has not done away with class antagonisms. It has but established new classes, new conditions of oppression, new forms of struggle in place of the old ones.

Our epoch, ... possesses, however this distinctive feature: it has simplified the class antagonisms. Society as a whole is more and more splitting up into two great hostile camps, into two great classes directly facing each other... ${ }^{30}$

${ }^{26}$ Engels (n 19) 582-583.

${ }^{27}$ See, Bhimrao Ramji Ambedkar, The Untouchables: Who were They and Why They Became Untouchables? (Amrit Book Depot 1948).

${ }^{28}$ For an interpretation of the Ambedkarite Theory, see, Alex George and S. Anand (eds), Beef, Brahmins and Broken Men: An Annotated Critical Selection from The Untouchables (Navayana 2019) 351-374.

${ }^{29}$ Engels (n 20) 35 .

${ }^{30}$ ibid 36. 
In our opinion, these two antagonistic classes (camps, groups, blocs or however else one would designate them) are those of the rich, powerful exploiters and the poor, helpless, subordinated Broken Men.

\section{Fragmentation of Broken Men}

Historical materialism quite scientifically and vividly explains the emergence of Broken Men at a certain point of progressive development of human society. Our task here is not to explore the historical conditions leading to the emergence of Broken Men. It is an accepted truth that from amongst the 'equals' sprouted groups of people who no longer belonged to the 'equals' and were subordinated to the remaining 'equals' is an outcome of crude and ruthless denial of their inherent and universal right to 'dignity'. Thus, birth of Broken Men is not of recent origin, but what makes the situation of Broken Men in the contemporary world critically vulnerable is the multifaceted fragmentation of Broken Men. Quite interestingly, this fragmentation process continues to take place both at the domestic as well as at the international levels. In the next following segments of this article we will try to identify some key ingredients of the process of fragmentation of Broken Men.

The single most significant factor accountable for fragmentation of Broken Men and withering importance of human rights is the disintegration of the former Soviet Union and corresponding fall of socialism as a world order. As long as we had the bipolar world, there existed checks and balances on the otherwise 'uncurtailed sovereign authority' of states. The world order based on two centres with two opposing ideologies and two different approaches to human rights jurisprudence as a matter of fact, crystalized basic tenets of human rights into international law of which some even attained the status of jus cogens. Existence of the two economic systems created an environment wherein no single category of human rights, civil, political, economic, social, cultural or otherwise could be ignored at the global level though individual states were at relative liberty to attach priority to certain category of rights. Dissolution of the Soviet Union and of socialism was a devastating blow to human rights in general and consequential negative impact on individual rights in particular.

The Uni-polar world that succeeded the fall of socialism tilted to and embraced (there being no alternative) Western form of democracy and governance with all their pitfalls. In the economic sphere, capitalism forgot about all niceties, began ignoring the call for capitalism to 'have a human face', crushed on workers' rights, and reverting back to the days of 'commodity fetishism.' Human dignity became primary casualty.

International law similarly felt the brunt of the change of epochs and attempts are abound to either impose 'new' principles of international law (guaranteeing supremacy of the West in international affairs) or re-interpret hitherto existing and 
universally recognized basic principles of international law. ${ }^{31}$ In such a scenario, Broken Men continue to remain invisible, neglected, ignored. The principles like 'sovereign equality of states' or 'territorial integrity', or principle of 'non-interference in the domestic affairs' are all but gone with the wind. Under the guise of 'War on Terror', use of illegitimate force, repugnant violation of territorial integrity of sovereign states, 'trampling of the 'right to life' of unarmed civilians have become everyday game of the big, powerful states vis-à-vis smaller and weaker in military and economic sense states. In overwhelming majority of cases, Broken Men pay the penalty of the whims and caprices of the more powerful- the wealthy exploiters.

Fragmentation of Broken Men is also accelerated by the unfortunate trend of a bend toward the right in international politics and governance. It became more than evident when the self-proclaimed leader of the world, the US President Donald Trump declared from the podium of the general Assembly of the United Nations that "the future of the world belongs not to the globalists (read human rights activists and defenders- M.R.) but the patriots (read ultra-nationalists, i.e. fascists-M.R.)" ${ }^{32}$ Such a shift in the policy of a country like the Unites States has had a catastrophic impact upon international relations: not only the state that had for long pursued human rights as a core foreign policy agenda took a sharp turn to the right but it led to resurgence of reactionary, authoritarian and dictatorial regimes at the helm of power in different countries around the globe. Interestingly, everywhere the change of guards has been taking place under the guise of 'democratic governance'. The situation has been worsening so rapidly that even the human rights defenders failed to notice exactly when the much appreciated and universally recognized conception of 'rights-based approach' was emptied of its contents and became a hollow slogan paving the path for a smooth upward ride of 'charity-based approach'. The offerors are the 'benevolent, kind-hearted', rich and elite rulers whereas the offerees are Broken Menthe poor, vulnerable, marginalized mass people whose mere existence depends on the 'charity' and 'kindness' of the ruling elites.

Radical changes in international relations are intertwined with further fragmentation of Broken Men at the domestic level. How this fragmentation works may be looked into from economic analysis of development projects in a country like Bangladesh. But let me remind the reader that in lieu of Bangladesh you are free to use the name of any country but the result will not be much different. A reputed political economist of Bangladesh, Prof. Abul Barkat writes:

Bangladesh is a rich country but its people are not wealthy. Bangladesh is rich because (a) it is rich in land, (b) rich in water bodies, (c) rich in forests, and (d) rich in human resources - people. But the reality is that there exists huge gap in the

\footnotetext{
${ }^{31}$ See more, Mizanur Rahman, 'Right to Peace and Human Rights' (n3) 172-181.

${ }^{32}$ See, Mizanur Rahman, 'Keynote paper: Stand Up for Your Rights' (n 4) 13.
} 
relationship between the first three riches with the last one- people. This gap (which is also a deviation) is illustrated in that the men who till the land and produce the wealth (paddy, jute, agricultural products etc.) do not own the land; the men (fisherman) who create wealth in the water bodies (breeds and catches fish) do not own the water body; and the men who put their labour in the jungles and forests and produces wealth (creates and protects the forests) do not own that forest. This detachment is a core reason of impoverishment of the people- the producers of wealth",33 and their further fragmentation.

As if to match this economic reality, governance at the domestic level is increasingly becoming what we may call 'democratic authoritarianism'. Today, populism has displaced nationalism-the core foundation of nation states. What is even more alarming is that populism is being fuelled by ultra-nationalism, religious fundamentalism/extremism, racial discrimination and ultimately a clash of civilizations- West versus the East, the rich North versus the poor South. Ultimate victims of all such 'excesses' are the Broken Men. A layman's inquiry into the recent events in Yemen, Syria, Afghanistan, or even 'secular' India would provide ample examples.

On the human rights sector, authoritarian regimes willing desperately to portray them as 'democratic' and 'people-friendly', are increasingly usurping the rights-based logic for effecting economic, social and cultural (ESC) rights and bringing those under their monopoly domain to show case the benevolent nature of their authority. Thus, notwithstanding the courageous move by the Himalayan country Nepal to proclaim ESC rights as fundamental rights of the citizens, vast majority of the members of the international community continue to consider ESC rights as benefits of 'charity' or 'kindness' of the ruling class. In so doing, the rulers forget that while doing charity may be an element of dignity of the bestower, charity per se is an element of indignity of the bestowed and therefore, not commensurate with human rights!

Authoritarian character of governments is so evident today that the rulers decide what is good for the ruled, the latter not even having any right to consultation. Governance is rapidly sliding away from the people, people-centric governance exists in text books only and 'democracy' is essentially becoming a right of the 'few' vis-à-vis the rest of the population. The Secretary General of the United Nations quite aptly mentioned:

democracy is inherently attached to the question of governance, which has an impact on all aspects of development efforts. They are linked because democracy is a fundamental human right, the advancement of which is itself an important measure of development. They are linked because people's participation in the decisionmaking processes which affect their lives is a basic tenet of development. ${ }^{34}$

${ }^{33}$ Abul Barkat, Political Economy of Agrarian-Land-Aquarian Reforms in Bangladesh (in Bangla) (Muktobuddhi 2016). (extracts on the back cover of the book)

${ }^{34}$ An Agenda for Development, Report of the Secretary General on Development and International Economic Cooperation. UNGAOR, $18^{\text {th }}$ Session, agenda item 91; 120 UN doc. A/48/935 of 1994. 
In the present day world when the international community is pursuing the policy of sustainable development goals popularly known as the SDGs, the Broken Men are being further distanced from the process of development — development is increasingly being defined as infrastructural development - constructing huge buildings and structures, express ways and subways, implementation of various mega-projects etc. without even inquiring whether the citizens are in favour of such development projects. Thus development strategy has failed to take into account the crux of all development initiatives - human development. The question is only but logical — can development be sustainable without human development?

In many jurisdictions the situation has become so authoritarian that questioning the scientific sustainability of any development project is considered as seditious and the consequence quite repressing for the Broken Men - unlawful detention, preventive detention (another way of trying to impute legitimacy to otherwise unlawful detention), extrajudicial killing, enforced disappearance, etc. have become the main tools of governance. Correspondingly, human rights are on the wane and the figure of the Broken Men is further fragmented and belittled.

\section{Globalization and Human Rights}

Globalization is both a cause and consequence of a unipolar world. If unipolarism, as evidenced from discussion above, has squeezed Broken Men in terms of human dignity and rights, globalization has further augmented the process and has thrown them from the frying pan to fire. Globalization has made the rich richer, and the poor poorer - both nationally as well as internationally. Inequality is inherent in the process of globalization. Writes an author:

Economic globalization violates human rights more than it protects. This is partly due to its dogmatic adherence to the elusive virtues of neo-liberal free market orientation and partly due to its marginalizing effects on the sovereign competence of the state. The driving forces of economic globalization such as MNCs, the World Bank, the IMF and the WTO, operate transnationally without the constraint of jurisdictional limitations. Whereas the overwhelming majority of states, because of their inferior economic, political and strategic clouts can hardly exert any influence beyond their domestic jurisdiction, which is constantly being circumscribed by economic globalization. Global economic actors are becoming more powerful than states. Consequently, when human rights within a state are infringed by the policies and practices of global economic actors, the power of the former to prevent such infringement is bewildered by the power of the latter. This lopsided power balance between the competing interests results in human rights transgressions with impunity. ${ }^{35}$

${ }^{35}$ M. Rafiqul Islam, 'Protecting Human Rights in an Era of Globalization' in Dr. Mizanur Rahman (ed), Human Rights and Globalization (ELCOP 2003) 29. 
It is not that transgressions of human rights take place only from across the borders, but very much within the boundaries of a nation state by its own 'democratic' rulers. While bad habits die hard, bad practices are embraced quicker. Thus if the Israeli onslaught on the Palestinians fighting for their right to self-determination continues with more brutality and impunity, if the Rohingyas are driven out of their motherland by the Myanmar regime through a policy no less than ethnic cleansing and genocide, if human rights sentinels of the West close their borders not to allow any refugees into their territories, when in pursuing its ultra-nationalistic objective of "Make America great again", the US construct mountain high walls along its borders with Mexico ( we could continue with the list of such infringements of rights), the authoritarian governments elsewhere on the globe feel encouraged, stimulated and strong to subdue dissent on the national plane leading to further fragmentation of Broken Men. This, in a nutshell, is the picture of human rights in a globalized world.

\section{Dead End for Human Rights?}

The weakening figure of Broken Men in this globalized world is quite frustrating, to say the least. But does this mean a farewell to human rights for Broken Men? Not at all.

At least in our part of the globe we are witness to a movement gradually gaining momentum and which is thought to be the strategy to empower Broken Men. We fondly call this movement Rebellious Lawyering and those involved as the Rebellious Lawyers. ${ }^{36}$ Elsewhere Prof. Rahman wrote:

...rebellious lawyering has already begun spreading its roots and will definitely usher in the true age of emancipation of the common people. The works of the rebellious lawyers are giving voice to the voiceless, power to those who believed in their destiny to live as the subordinated, making the hitherto invincible poor and the downtrodden visible in the eye of the law and the policy makers....

Fundamental changes are in the offing and the rebellious lawyers are the glorious changemakers. These lawyers are dressed in traditional lawyers' outfits, sharing the chambers with traditional lawyers, walking the same corridors of law and power but endowed with un-parallel inner strength of mind. They know that their path is the true path of empowerment of the common people, they believe that it is not individual good but the common good they aspire for, they are convinced that true emancipation happens only when human dignity is protected, ensured and guaranteed at all times. They are taking huge steps yet making no sound. But their apparent seeking of solace in silence is leading to fundamental changes in how we live our lives in the future. The change is colossal. This is what we call a revolution. ${ }^{37}$

Verily, there is nothing for Broken Men to despair!

${ }^{36}$ On Rebellious Lawyers and Rebellious Lawyering, see, Mizanur Rahman, Anti-Generic Learning and Rebellious Lawyering: Reflections on Legal Education in Bangladesh (Bijoy Prakash 2018) 208.

${ }^{37}$ Mizanur Rahman, 'The Story of Rebellious Lawyering or Approaching of a Silent Revolution' in Dr. Mizanur Rahman and others (eds), Human Rights and Rebellious Lawyering (ELCOP 2019) 11-12. 